\title{
Generalized Simulation Model of Nanostructure Self-Formation Process by Anodic Oxidization of Aluminum and Titanium
}

\author{
Alexey N. Belov ${ }^{1, *}$, Vasily I. Shevyakov ${ }^{1}$, Alexander V. Solnyshkin ${ }^{1,2}$, Maxim I. Vorobiev ${ }^{1}$ \\ ${ }^{1}$ Department of Intellectual Technical Systems, National Research University "MIET", Moscow, \\ Zelenograd, 124498, Russia \\ ${ }^{2}$ Department of Condensed Matter Physics, Tver State University, Tver, 170100, Russia \\ *E-mail: nanointech@mail.ru
}

doi: $10.20964 / 2016.12 .55$

Received: 10 September 2016 / Accepted: 11 October 2016 / Published: 10 November 2016

The computer simulation results of physicochemical process of nanopore formation in aluminum and titanium oxides are presented in this paper. The model based on an electric field distribution in an electrochemical cell takes into account oxide formation and dissolution reactions on metal-oxide and oxide-electrolyte boundaries, respectively. Such an approach allows to describe geometric characteristics dependences of the nanostructured oxide layers on electrophysical and chemical parameters throughout the formation process. The experimental results confirm the proposed model validity.

Keywords: nanoporous metal oxide, self-formation, simulation

\section{FULL TEXT}

(C) 2016 The Authors. Published by ESG (www.electrochemsci.org). This article is an open access article distributed under the terms and conditions of the Creative Commons Attribution license (http://creativecommons.org/licenses/by/4.0/). 